\section{Efektivitas penggunaan poster dan video dalam meningkatkan pengetahuan dan sikap tentang buah dan sayur pada siswa Dayah Terpadu Inshafuddin}

\section{The effectiveness of the use of posters and videos on increasing knowledge and attitudes about vegetables and fruit among students at Dayah Terpadu Inshafuddin}

Jellyfa Indah ${ }^{1}$, Junaidi ${ }^{2}$
SAGO: Gizi dan Kesehatan 2021, Vol. 2(2) 129-135 (c) The Author(s) 2021

DOI: http://dx.doi.org/10.30867/gikes.v2i2.311 https://ejournal.poltekkesaceh.ac.id/index.php/

Poltekkes Kemenkes Aceh

\begin{abstract}
Background: The World Health Organization (WHO) generally recommends the consumption of vegetables and fruit for a healthy life of 400 grams per person per day, consisting of 250 grams of vegetables and 150 grams of fruit. Not all Indonesians consume fruits and vegetables as much as $97.3 \%$ consume vegetables $73.6 \%$ consume fruit, nutrition education with audio-visual media is effective in increasing students' knowledge.

Objective: This study aims to measure the effectiveness of poster and video media in increasing students' knowledge and attitudes about fruits and vegetables at Dayah Terpadu Inshafuddin.

Methods: This study used a quasi-experimental research design (quasi-experimental). The sample in this study was all students of class 2A and 2C Dayah Terpadu Inshafuddin Banda Aceh, with the study time in 2019. Data collection used a questionnaire and direct interviews were conducted. The data is processed using computer applications. Data analysis using T-Dependent and T-Independent test.

Results: The results showed that students' knowledge of vegetables and fruit increased to $83.6 \%$, and attitudes increased to $84.5 \%$. There was an increase in students' knowledge and attitudes about fruits and vegetables between before and after counseling $(p<0.05)$. In addition, it also showed that there was a significant effect of counseling using videos and posters $(p<0.05)$.

Conclusion: The use of poster and video media can increase students' knowledge and attitudes, and using video media is more effective than posters in increasing knowledge and attitudes about vegetable and fruit consumption.
\end{abstract}

\title{
Keywords
}

Attitudes, fruits and vegetables, knowledge, poster media, video media

\begin{abstract}
Abstrak
Latar Belakang: World Health Organization (WHO) secara umum menganjurkan konsumsi sayur dan buah untuk hidup sehat sejumlah $400 \mathrm{gr}$ per orang per hari, yang terdiri dari 250 gr sayur dan $150 \mathrm{gr}$ buah. Tidak semua penduduk Indonesia mengonsumsi buah dan sayur sebanyak $97.3 \%$ mengonsumsi sayur $73.6 \%$ mengonsumsi buah, edukasi gizi dengan media audio visual efektif untuk meningkatkan pengetahuan siswa.

Tujuan: Penelitian bertujuan untuk mengukur efektivitas media poster dan video dalam meningkatkan pengetahuan dan sikap siswa tentang buah dan sayur di Dayah Terpadu Inshafuddin.

\footnotetext{
1 Proram Studi Gizi, Jurusan Gizi Politeknik Kesehatan Kemenkes Aceh, Aceh, Indonesia. E-mail: Marysofia1996@gmail.com

2 Jurusan Gizi Politeknik Kesehatan Kemenkes Aceh, Aceh, Indonesia. E-mail: Junaidineidi@gmail.com

Penulis Koresponding:

Jellyfa Indah: Proram Studi Gizi, Jurusan Gizi Politeknik Kesehatan Kemenkes Aceh. Jl Soekarno-Hatta, Kampus Terpadu, Km. 8, Lampeunerut Aceh Besar, Aceh, Indonesia. E-mail: Marysofia1996@gmail.com
} 
Metode: Penelitian ini menggunakan rancangan penelitian quasi eksperimen (eksperimen semu). Sampel dalam penelitian adalah seluruh siswa kelas 2A dan 2C Dayah Terpadu Inshafuddin Banda Aceh, dengan waktu studi yaitu tahun 2019. Pengumpulan data menggunakan kuesioner dan dilakukan wawancara secara langsung. Data diolah menggunakan aplikasi computer. Analisis data menggunakan uji T-Dependent dan T-Independent.

Hasil: Hasil diketahui bahwa pengetahuan siswa tentang sayur dan buah meningkat menjadi 83.6\%, dan sikap meningkat menjadi $84.5 \%$. Terdapat peningkatan pengetahuan dan sikap siswa tentang buah dan sayur antara sebelum dan setelah penyuluhan $(p<0.05)$. Selain itu, juga menunjukkan terdapat pengaruh signifikan penyuluhan menggunakan video dan poster $(p<0.05)$.

Kesimpulan: Penggunaan media poster dan video dapat meningkatkan pengetahuan dan sikap siswa, dan menggunakan media video lebih efektif dibandingkan poster dalam meningkatkan pengetahuan dan sikap tentang konsumsi sayur dan buah.

\section{Kata Kunci}

Buah dan sayur, media video, media poster, pengetahuan, sikap

\section{Pendahuluan}

W orld Health Organization (WHO) secara umum menganjurkan konsumsi sayur dan buah untuk hidup sehat sejumlah 400 gr per orang per hari, yang terdiri dari $250 \mathrm{gr}$ sayur dan 150 gr buah (Rippe, 2019). Bagi orang Indonesia dianjurkan untuk konsumsi sayur dan buah 300-400 gr per orang per hari bagi anak balita dan usia sekolah, dan 400-600 gr per orang per hari bagi remaja dan orang dewasa (Isnaningsih, 2019). Sekitar 2/3 dari jumlah konsumsi sayur dan buah tersebut adalah sayur (Rahmad \& Almunadia, 2017).

Konsumsi buah dan sayur di Indonesia tahun 2016, kurang dari setengah konsumsi yang direkomendasikan, sebagian besar penduduk Indonesia mengonsumsi buah dan sayur sebanyak 173 gr per hari, lebih kecil dari angka kecukupan gizi (AKG) yang direkomendasikan yaitu sebesar $400 \mathrm{gr}$ perkapita per hari (Balitbangkes, 2014). Konsumsi buah lebih sedikit daripada konsumsi sayur yaitu 67 gr sedangkan sayur sebesar 107 gr per kapita per hari. Selanjutnya, tidak semua penduduk Indonesia mengonsumsi buah dan sayur sebanyak $97.3 \%$ mengonsumsi sayur 73.65 mengonsumsi buah. Konsumsi sayur dan buah pada setengah dari seluruh provinsi di Indonesia di bawah rata-rata konsumsi nasional (173 gram per kapita per hari) untuk Provinsi Aceh konsumsi buah dan sayur masih di bawah rata-rata konsumsi nasional (Kemenkes RI, 2017).

Menurut Azhari \& Fayasari (2020), konsumsi sayur dan buah yang rendah dapat menyebabkan beberapa masalah gizi pada anak, salah satunya adalah obesitas pada anak usia sekolah. Azadirachta \& Sumarmi (2017) menyebutkan anak yang kurang konsumsi serat dapat mengalami gangguan saluran pencernaan, seperti mengalami konstipasi dan kegemukan. Pengetahuan merupakan salah satu faktor yang mempengaruhi konsumsi sayur dan buah pada anak. Penelitian Waryana et al. (2019), menyatakan bahwa pengetahuan berhubungan dengan sikap seseorang dalam mengonsumsi sayur dan buah.

Media pendidikan dan kesehatan merupakan sebuah sarana sebagai proses penyampaian informasi dari komunikator kepada komunikan yang disampaikan melalui media cetak, elektronik dan media luar ruang, sehingga sasaran di harapkan dapat meningkatkan pengetahuan yang akhirnya dapat mengubah perilaku sasaran (Chandio et al., 2016). Perilaku seseorang meliputi pengetahuan, sikap, dan tindakan. Perilaku dapat dikelompokkan menjadi periaku terbuka (overt behavior) yaitu respon seseorang terhadap suatu objek secara terbuka dan nyata dalam bentuk tindakan yang dapat diamati oleh orang lain, sedangkan perilaku tertutup (covert behavior) yaitu respon seseorang dalam bentuk tertutup atau terselubung. Respon tersebut masih dalam batas perhatian, persepsi, pengetahuan/kesadaran dan sikap pada orang tersebut, sehingga tidak bisa diamati langsung oleh orang lain (Notoatmojo, 2014).

Edukasi dengan media audio visual adalah salah satu upaya pembelajaran yang menggabungkan beberapa media yaitu media audio (suara) dan visual (penglihatan). Video merupakan salah satu contoh produk dari media audio visual, video dibuat dengan merekam suatu objek baik nyata seperti rekaman bencana alam maupun tiruan seperti kartun animasi. Terdapat perbedaan peningkatan hasil belajar antara siswa yang menggunakan dengan yang tidak menggunakan media audio visual pada pembelajaran Bahasa Inggris. Perbedaan yang terjadi ini menunjukkan bahwa media audio visual berpengaruh positif 
terhadap peningkatan hasil belajar siswa (Muttaqien, 2017). Berdasarkan penelitian Meidiana et al. (2018) menunjukkan bahwa edukasi gizi dengan media audio visual efektif untuk meningkatkan pengetahuan pada remaja atau siswa yang overweight. Seperti penelitian yang dilakukan oleh Tuzzahroh (2015), bahwa media video, poster dan permainan kwarted berpengaruh terhadap pengetahuan gizi siswa.

Poster memiliki keunggulan dan daya tarik lebih tinggi karena menonjolkan kekuatan pesan, visual dan warna. Poster dapat berupa gambar yang memiliki warna yang menarik sehingga dapat menangkap perhatian orang dengan menanamkan suatu makna tertentu yang ingin disampaikan oleh pembuat poster, sesuai dengan tujuan poster tersebut. Penggunaan media poster dapat meningkatkan kemampuan peserta didik dalam menggunakan bahasa asing seperti menulis, membaca, mendengarkan serta bertanya jawab (Megawati, 2017). Oleh karena itu, berdasarkan kajian latar belakang diatas maka penelitian ini bertujuan untuk mengetahui efektivitas media poster dan video dalam meningkatkan pengetahuan dan sikap pada siswa Dayah Terpadu Inshafuddin Banda Aceh.

\section{Metode}

Jenis penelitian ini bersifat kuantitatif dengan pendekatan quasi eksperimen (eksperimen semu) dimana bentuk desain yang dipakai adalah two group pretest dan posttest yaitu untuk mengetahui efektivitas peningkatan pengetahuan dan sikap tentang konsumsi sayur dan buah menggunakan media audio visual dengan media visual (poster) di Dayah Terpadu Inshafuddin Banda Aceh sebelum dan sesudah penyuluhan.

Populasi dalam penelitian adalah seluruh siswa kelas 2A dan 2C Dayah Terpadu Inshafuddin Banda Aceh. Populasi ini dianggap sesuai dengan kriteria yang diharapkan oleh peneliti karena memiliki jadwal belajar yang fleksibel pada saat penelitian ini berlangsung.

Pengambilan sampel dalam penelitian ini menggunakan teknik total sampling sehingga sampel dari penelitian ini adalah seluruh populasi siswa kelas 2A dan 2C Dayah Terpadu Inshafuddin yang dibagi menjadi dua kelompok dengan kriteria sampel sebagai berikut: a) Merupakan murid kelas 2A dan 2C Dayah Terpadu Inshafuddin. b) Bersedia menjadi sampel. c) Hadir pada saat penyuluhan, dan d) Bersedia mengikuti penyuluhan dan mengisi angket pretest dan posttest.

Variabel dalam penelitian ini adalah variabel independen dan variabel dependen, dimana variabel independen adalah penyuluhan konsumsi sayur dan buah dan variabel dependen adalah efektivitas peningkatan pengetahuan siswa/i Dayah Terpadu Inshafuddin.

Data yang diperoleh langsung dari objek penelitian meliputi identitas sampel,pengukuran pengetahuan dan sikap melalui pre test dan post test tentang konsumsi sayur dan buah, sebelum dan sesudah penyuluhan. Data sekunder dalam penelitian ini meliputi semua data-data yang mendukung kelengkapan data primer seperti gambaran umum, keadaan lokasi penelitian dan data tentang jumlah sampel yang ada di Dayah Terpadu Inshafuddin.

Analisis statistik dalam mengemukakan hipotesis yang diajukan yaitu menggunakan uji paired t-test dan Independent t-test dengan tingkat kemaknaan yaitu sebesar $95 \%$.

\section{Hasil}

\section{Karakteristik Responden}

Berdasarkan hasil penelitian (Tabel 1) menunjukkan bahwa umur responden pada dua kelompok tersebut terlihat bahwa, mayoritas sampel berjenis kelamin perempuan dengan usia antara 13-14 tahun pada kedua kelompok intervensi.

Tabel 1. Karakteristik responden

\begin{tabular}{lcccc}
\hline \multirow{2}{*}{$\begin{array}{c}\text { Karakteristik } \\
\text { Responden }\end{array}$} & \multicolumn{5}{c}{ Media Intervensi } \\
\cline { 2 - 5 } & \multicolumn{1}{c}{ Media Video } & Media Poster \\
\cline { 2 - 5 } & $\mathrm{f}$ & $\%$ & $\mathrm{f}$ & $\%$ \\
\hline $\begin{array}{c}\text { Jenis Kelamin } \\
\text { Laki-laki }\end{array}$ & 10 & 37.0 & 5 & 25.0 \\
$\begin{array}{l}\text { Perempuan } \\
\text { Umur }\end{array}$ & 17 & 63.0 & 15 & 75.0 \\
11-12 tahun & 5 & 18.5 & 3 & 15.0 \\
13-14 tahun & 22 & 81.5 & 17 & 85.0 \\
\hline Jumlah & 27 & 100.0 & 20 & 100.0 \\
\hline
\end{tabular}

\section{Pengaruh Penyuluhan Menggunakan Media Video} dan Poster terhadap Pengetahuan dan Sikap

Berdasarkan hasil analisis data (Tabel 2) pada kategori pengetahuan sebelum dilakukan penyuluhan dengan menggunakan dua metode yang berbeda, rata-rata mendapatkan skor 
pengetahuan sebesar $63.3 \%$ akan tetapi setelah dilakukan penyuluhan peningkatan pengetahuan Siswa meningkat sebanyak $20.2 \%$ menjadi $83.6 \%$ ini dikategorikan baik. Begitu juga yang terjadi pada kategori sikap para siswa, sebelum dilakukan penyuluhan dengan menggunakan dua metode yang berbeda mendapatkan skor sebesar $55.5 \%$ setelah dilakukan penyuluhan mengalami peningkatan sebanyak $27.9 \%$ menjadi $84.5 \%$. Secara statistik terbukti bahwa terdapat perbedaan signifikan $(p<0.05)$ antara pengetahuan sebelum dengan setelah diberikan media video dan poster $(p=0,000)$, serta perbedaan sikap antara sebelum dengan setelah diberikan media video dan poster $(p=0,000)$ tentang tentang buah dan sayur di Dayah Inshafuddin Banda Aceh.

Tabel 2. Pengaruh pemberian media video dan poster terhadap peningkatan pengetahuan dan sikap siswa tentang sayur dan buah

\begin{tabular}{lccccc}
\hline Variabel Intervensi & Rerata \pm SD & $\begin{array}{c}\text { Selisih Rerata } \pm \\
\text { SD }\end{array}$ & $\begin{array}{c}\text { Persentase } \\
\text { Skor }\end{array}$ & Cl: 95\% & Nilai $p$ \\
\hline Pengetahuan & & & & & \\
$\quad$ Sebelum intervensi & $63.38 \pm 10.705$ & $20.29 \pm 9.673$ & $63.3 \%$ & $17.4-23.1$ & 0.000 \\
$\quad$ Setelah Intervensi & $83.68 \pm 8.060$ & & $83.6 \%$ & & \\
Sikap & & & & & \\
$\quad$ & & & & \\
$\quad$ Sebelum intervensi & $56.57 \pm 9.648$ & $27.95 \pm 9.871$ & $56.5 \%$ & 25.000 \\
$\quad$ Setelah Intervensi & $84.53 \pm 4.804$ & & $84.5 \%$ & & \\
\hline
\end{tabular}

Tabel 3. Efektifitas penggunaan media video dan poster dalam meningkatan pengetahuan dan sikap siswa tentang sayur dan buah

\begin{tabular}{|c|c|c|c|c|c|c|c|}
\hline \multirow{2}{*}{$\begin{array}{l}\text { Kelompok } \\
\text { Intervensi }\end{array}$} & \multirow{2}{*}{$\mathrm{n}$} & \multirow{2}{*}{ Rerata } & \multirow{2}{*}{$\begin{array}{c}\text { Persentase } \\
\text { Skor }\end{array}$} & \multirow{2}{*}{$\begin{array}{l}\text { Perbedaan } \\
\text { Rerata } \pm \text { SD }\end{array}$} & \multicolumn{2}{|c|}{ Cl: 95\% } & \multirow[t]{2}{*}{ Nilai $p$} \\
\hline & & & & & Lower & Upper & \\
\hline \multicolumn{8}{|l|}{ Pengetahuan } \\
\hline Media Poster & 20 & 68.2 & $68.2 \%$ & $9.280 \pm 2.974$ & 1.815 & 13.793 & 0.012 \\
\hline Media Video & 27 & 77.4 & $77.4 \%$ & & & & \\
\hline \multicolumn{8}{|l|}{ Sikap } \\
\hline Media Poster & 20 & 68.4 & $68.4 \%$ & $0.5 \pm 2.745$ & 0.260 & 5.746 & 0.041 \\
\hline Media Video & 27 & 68.9 & $68.9 \%$ & & & & \\
\hline
\end{tabular}

\section{Efektifitas Penggunaan Video dan Poster Sebagai Media Penyuluhan dalam Meningkatkan Pengetahuan dan Sikap}

Secara deskriptif, hasil penelitian sebagaimana disajikan pada tabel 3 menunjukkan bahwa pada kelompok data pengetahuan penyuluhan menggunakan dua media yaitu media poster dan media video mempunyai nilai perbedaan rerata 9.280 atau setara dengan $9.2 \%$ dari total skor yang diperoleh, yang berarti nilai kelompok pada media video lebih tinggi dibandingkan dengan media poster, akan tetapi nilai yang didapat oleh media poster tidak terlalu jauh perbedaannya dan masih dikategorikan baik.

Sedangkan pada kelompok data sikap menggunakan penyuluhan dengan dua media nilai perbedaan rerata yaitu 0.5 atau setara dengan $0.5 \%$ dar total skor yang diperoleh. Dapat disimpulkan bahwa, dari perbandingan dua kelompok media poster dan video tersebut terdapat perbedaan yang signifikan $(p<0.05)$ dalam meningkatkan pengetahuan dan sikap. Berdasarkan nilai skoring (persentase) diketahui bahwa, penggunaan media video lebih baik dalam meningkatkan pengetahuan dan sikap jika dibandingkan menggunakan media poster.

\section{Pembahasan}

Pengaruh Penggunaan Media Video dan Poster Terhadap Peningkatan Pengetahuan dan Sikap Siswa tentang Konsumsi Sayur dan Buah

Hasil penelitian menunjukkan bahwa adanya perbedaan yang signifikan antara pengetahuan sebelum penyuluhan dan sesudah penyuluhan $(p<$ 0.05 ). Terdapat beberapa metode penyuluhan yang dilakukan oleh peneliti untuk mengetahui tingkat 
pengetahuan anak sekolah tentang sayur dan buah. Metode yang digunakan adalah metode ceramah menggunakan media poster dan video yang dilakukan di kelas $2 \mathrm{~A}$ dan $2 \mathrm{C}$ pada anak sekolah dan menunjukkan pengaruh yang bermakna untuk meningkatkan pengetahuan Siswa tentang Sayur dan buah di Dayah Inshafuddin tahun 2019. Media sangat mempengaruhi sebuah penyuluhan karena dapat membantu dan mempermudah dalam penyampaian materi dan alat bantu untuk memperagakan sesuatu yang ingin disampaikan oleh penyuluh (Al Rahmad, 2018). Sedangkan menurut Fitri et al. (2020), berpendapat berhasilnya suatu penyuluhan tergantung pada metode dan media yang digunakan pada penyuluhan tersebut.

Media promosi kesehatan adalah salah satu sarana atau upaya yang dapat digunakan untuk menampilkan pesan atau informasi kesehatan yang akan disampaikan kepada remaja sehingga dapat meningkatkan pengetahuannya dan akhirnya diharapkan berubah perilakunya kearah yang lebih positif dan mendukung terhadap kesehatan. Penggunaan metode penyuluhan dan media penyuluhan yang tepat dapat meningkatkan efisiensi dan efektifitas dalam pelaksanaan penyuluhan kesehatan di masyarakat (Alini \& Indrawati, 2018). Hal ini sesuai dengan penelitian yang dilakukan oleh Yulinda \& Fitriyah (2018) yang mengatakan bahwa terdapat pengaruh pendidikan kesehatan dengan metode audiovisual, dikarenakan pesan yang disampaikan dapat diterima dengan baik oleh responden. Artinya bahwa keberhasilan penyuluhan dapat dipengaruhi oleh media karena media dapat mempengaruhi pengetahuan, sikap dan emosi.

Hal ini didukung pula dengan teori yang mengatakan bahwa pemilihan dan penggunaan alat bantu media merupakan salah satu komponen yang penting dilakukan pada saat penelitian, tujuannya agar membantu penggunaan indra sebanyakbanyaknya (Notoatmojo, 2014). Seseorang mendapat pengetahuan melalui panca inderanya, dimana sebagian besar diperoleh melalui indera penglihatan (mata) yaitu sebesar $83 \%$ dan indera pendengar (telinga) yaitu sebesar $11 \%$, sedangkan sisanya melalui indera perasa $1 \%$, indera peraba $2 \%$ dan ndera penciuman 3\% (Merita, 2019). Hal ini sesuai teori yang dikemukakan oleh Majid (2006), bahwa media penyuluhan kesehatan melalui media video memiliki beberapa keuntungan yaitu lebih menarik dan lebih mudah dipahami, dengan video seseorang dapat belajar sendiri, dapat diulang pada bagian tertentu yang perlu lebih jelas, dapat menampilkan sesuatu yang detail, dan dapat dipercepat maupun diperlambat.

\section{Efektifitas Penggunaan Video dan Poster Sebagai Media Penyuluhan dalam Meningkatkan Pengetahuan dan Sikap}

Hasil penelitian telah menunjukkan bahwa media video lebih berperan dalam meningkatkan perilaku yang dimiliki oleh siswa dibandingkan dengan media poster.

Media video salah satu media intraksional modern yang sesuai dengan perkembangan zaman (kemajuan ilmu pengetahuan dan teknologi) meliputi media yang dapat dilihat dan didengar. Menurut Lufianti (2010) dengan menggunakan video pesan yang disampaikan lebih menarik perhatian dan motivasi bagi penonton. Pesan yang disampaikan lebih efisien karena gambar bergerak dapat mengkomunikasikan pesan dengan cepat dan nyata. Oleh karena itu, dapat mempercepat pemahaman pesan secara lebih komprehensif. Seseorang setelah mengetahui stimulus atau objek kesehatan, kemudian mengadakan penilaian atau pendapat terhadap apa yang diketahui, proses selanjutnya diharapkan responden akan melaksanakan atau mempraktekkan apa yang diketahui (Streiner et al., 2015).

Menyampaikan dengan audiovisual lebih efektif karena penyajian secara audiovisual membuat penonton lebih berkonsentrasi. Hal ini sesuai dengan teori yang dikatakan oleh Sadiman et al. (2012), bahwa video dapat memberikan stimulus terhadap pandangan dan pendengaran dengan memegang prinsip psikomotor, behavioristik, dan kognitif, sehingga responden bisa menerima informasi melalui indra pendengar yaitu telinga dan indra penglihatan yaitu mata, sehigga informasi yang disampaikan dapat diterima secara maksimal. Video diharapkan sama seperti film, dapat merangsang pikiran, perasaan, perhatian dan kemauan sehingga dapat mendorong terjadinya perubahan pengetahuan, seperti penjelasan Azadirachta \& Sumarmi (2017) mengemukakan bahwa pancaindra yang banyak menyalurkan pengetahahuan ke otak adalah mata yaitu lebih kurang $75 \%$ sampai dengan $87 \%$, selebihnya disalurkan dari pancaindra yang lain.

\section{Kesimpulan}

Penggunaan media video dan media poster secara signifikan dapat meningkatkan pengetahuan dan sikap siswa tentang konsumsi sayur dan buah. 
Media video mempunyai nilai efektifitas yang lebih baik dibandingkan media poster dalam meningkatkan pengetahuan dan sikap tentang konsumsi sayur dan buah pada siswa di Dayah Terpadu Inshafuddin

Saran, dalam upaya mendukung pengentasan masalah stunting serta promosi kesehatan dan gerakana masyarakat sehat, maka sangat penting dilakukan upaya-upaya penyuluhan tentang konsumsi sayur dan buah menggunakan media video. Media tersebut dapat lebih dikembangkan lagi secara baik dan berkualitas seperti dari segi durasi, konten, dan konstruknya. Media perlu diupload pada penyedia layanan streaming seperti youtube dan lainnya.

\section{Deklarasi Konflik Kepentingan}

Penulis telah menyatakan bahwa pada artikel ini tidak ada maupun terdapat potensi konflik kepentingan baik dari penulis maupun instansi sehubungan dengan penelitian yang telah dilakukan, baik berdasarkan kepengarangan, maupun publikasi.

\section{Ucapan Terima Kasih}

Ucapan terimakasih disampaikan kepada Ketua Jurusan Gizi Politeknik Kesehatan Kemenkes Aceh yang telah membantu kontribusi terhadap pelaksanaan penelitian. Selain itu, ucapan terima kasih juga kami sampaikan kepada Bapak pembimbing/ supervisor yang telah membantu perbaikan baik secara teknis maupun isi dalam pelaksanaan penelitian ini. Kepada pihak rumah sakit yang telah memberikan kesempatan dan membantu penulis dalam melakukan penelitian.

\section{Daftar Rujukan}

Al Rahmad, A. H. (2018). Pengaruh Pemberian Konseling Gizi terhadap Penurunan Kadar Kolesterol Darah. Jurnal Kesehatan, 9(2), 241247. https://doi.org/10.26630/jk.v9i2.947

Alini, \& Indrawati. (2018). Efektifitas Promosi Kesehatan Melalui Audio Visual Dan Leaflet Tentang SADARI (Pemeriksaan Payudara Sendiri) Terhadap Peningkatan Pengetahuan Remaja Putri Tentang Sadari di SMAN 1 Kampar tahun 2018. Jurnal Ners, 2(2), 1-9.
Azadirachta, F. L., \& Sumarmi, S. (2017). Pendidikan Gizi menggunakan media buku saku meningkatkan pengetahuan dan praktik konsumsi sayur dan buah pada siswa sekolah dasar. Media Gizi Indonesia, 12(2), 107-115.

Azhari, M. A., \& Fayasari, A. (2020). Pengaruh edukasi gizi dengan media ceramah dan video animasi terhadap pengetahuan sikap dan perilaku sarapan serta konsumsi sayur buah. AcTion: Aceh Nutrition Journal, 5(1), 55-61.

Balitbangkes. (2014). Laporan Survei Diet Total (SDT) 2014. In Badan Penelitian dan Pengembangan Kesehatan. Kementerian Kesehatan RI.

Chandio, M. T., Pandhiani, S. M., \& Iqbal, S. (2016). Bloom's taxonomy: Improving assessment and teaching-learning process. Journal of Education and Educational Development, 3(2), 203-221.

https://doi.org/http://dx.doi.org/10.22555/jo eed.v3i2.1034

Fitri, Y., Al Rahmad, A. H., Suryana, S., \& Nurbaiti, N. (2020). Pengaruh penyuluhan gizi tentang jajanan tradisional terhadap peningkatan pengetahuan dan perilaku jajan anak sekolah. AcTion: Aceh Nutrition Journal, 5(1), 13-18. https://doi.org/http://dx.doi.org/10.30867/a ction.v5i1.186

Isnaningsih, T. (2019). Pendidikan Kesehatan Melalui Media Booklet dan Audio Visual Untuk Meningkatkan Pengetahuan Tentang Konsumsi Buah dan Sayur. Indonesian Journal of Educational Science (IJES), 2(1), 48-56.

Kemenkes RI. (2017). Tingkatkan Konsumsi Sayur dan Buah Nusantara Menuju Masyarakat Hidup Sehat. In Kementerian Kesehatan Republik Indonesia.

Lufianti, A. (2010). Perbedaan Pengaruh Pembelajaran Perawatan Payudara (Breast Care) Dengan Video Compact Disc (Vcd) Dibanding Dengan Phantom terhadap Pengetahuan dan Motivasi Belajar (pada Mahasiswa D-III Keperawatan Sekolah Tinggi IImu Kesehatan An-Nur Purwodadi). In Universitas Sebelas Maret. Universitas Sebelas Maret.

Majid, A. (2006). Perencanaan Pembelajaran. Remaja Rosdakarya.

Megawati, M. (2017). Pengaruh Media Poster terhadap Hasil Belajar Kosakata Bahasa Inggris (Eksperimen di Sdit Amal Mulia Tapos Kota Depok). Getsempena English Education 
Journal, 4(2), 217637.

Meidiana, R., Simbolon, D., \& Wahyudi, A. (2018). Pengaruh Edukasi melalui media audio visual terhadap pengetahuan dan sikap remaja overweight. Jurnal Kesehatan, 9(3), 478-484.

Merita, M. (2019). Tumbuh Kembang Anak Usia 0-5 Tahun. Jurnal Abdimas Kesehatan (JAK), 1(2), 83-89.

Muttaqien, F. (2017). Penggunaan Media AudioVisual dan Aktivitas Belajar Dalam Meningkatkan Hasil Belajar Vocabulary Siswa pada Mata Pelajaran Bahasa Inggris Kelas $X$ (Quasy Experiment: SMAN 8 Garut). Jurnal Wawasan Ilmiah, 8(1), 25-32.

Notoatmojo, S. (2014). Ilmu Perilaku Kesehatan. Rineka Cipta.

Rahmad, A. H. Al, \& Almunadia, A. (2017). Pemanfaatan media flipchart dalam meningkatkan pengetahuan ibu tentang konsumsi sayur dan buah. Jurnal Kedokteran Syiah Kuala, 17(3), 140-146. https://doi.org/10.24815/jks.v17i3.9062

Rippe, J. M. (2019). Lifestyle strategies for risk factor reduction, prevention, and treatment of cardiovascular disease. American Journal of Lifestyle Medicine, 13(2), 204-212.

Sadiman, Arief, S., Rahardjito, R., \& Anung, H.
(2012). Media Pendidikan,Pengertian Pengembangan Dan Pemanfaatan. In Raja Grafindo Persada. Grafindo Persada.

Streiner, D. L., Norman, G. R., \& Cairney, J. (2015). Health measurement scales: a practical guide to their development and use. In Oxford University Press, USA. Oxford University Press, USA.

Tuzzahroh, F. (2015). Pengaruh Penyuluhan Gizi Seimbang Dengan Media Video,Poster dan Permainan Kwartet Gizi Terhadap Pengetahuan Gizi dan Status Gizi Siswa Di Sekolah Dasar Negeri Karangasem lii Kota Surakarta. Universitas Muhammadiyah Surakarta.

Waryana, W., Sitasari, A., \& Febritasanti, D. W. (2019). Intervensi media video berpengaruh pada pengetahuan dan sikap remaja putri dalam mencegah kurang energi kronik. AcTion: Aceh Nutrition Journal, 4(1), 58-62. https://doi.org/http://dx.doi.org/10.30867/a ction.v4i1.154

Yulinda, A., \& Fitriyah, N. (2018). Efektivitas penyuluhan metode ceramah dan audiovisual dalam meningkatkan pengetahuan dan sikap tentang sadari di SMKN 5 Surabaya. Jurnal Promkes, 6(2), 116-128. 